\title{
太陽光発電・燃料電池ハイブリッドシステムの基礎研究 （水素吸蔵合金を用いたシステムの特性）
}

\author{
学生員 関口直 俊 (東京理科大) \\ 正員 谷 辰夫 (東京理科大)

\begin{abstract}
Fundamental Study on Photovoltaic / Fuel Cell Power Hybrid System (Characteristic of System Utilized Hydrogen Absorbing Alloys)
\end{abstract}

Naotoshi Sekiguchi, Student Member, Tatsuo Tani, Member (Science University of Tokyo)

\begin{abstract}
Constructing the hydrogen energy system in a global scale as an energy system which have not affected a global environment is assumed. One of the hydrogen energy system is a photovoltaic / fuel cell power hybrid system which is a combination of the photovoltaic power generation system and fuel cell. This system is composed of photovoltaic arrays, hydrogen generators, hydrogen storage system and fuel cell power generation system. The hydrogen storage system is composed of three hydrogen storage tanks. Each hydrogen storage tank has hydrogen absorbing alloys (LaNi5) and a shell and tube heat exchanger. This system can supply constant electric power to the electric loads in a solitary island separated from a commercial electric network.

The possibility of each of hydrogen storage tank in this system is examined by the computer simulation. Input data used in this simulation are as follows ; the global irradiance on inclined plane and the ambient temperature of HASP data of Tokyo, residential load data which have ten kinds of electrical load forms (annual electric load energy of $400 \mathrm{MWh}$ ), conversion efficiencies of each subsystem and so on.

As a result of the computer simulation, it was reveled that $745 \mathrm{~kW}$ in rated capacity of photovoltaic power generation system, 259.2 tons in total weight of hydrogen absorbing alloys, $150 \mathrm{~kW}$ in rated capacity of fuel cell power generation system are needed for the annual electric load of $400 \mathrm{MWh}$. And then a number of hydrogen absorption and desorption of hydrogen storage tanks per year are 1039 and 1749 times respectively.
\end{abstract}

キーワード : 太陽光発電・燃料電池ハイブリッドシステム, 水素貯蔵装置, 水素吸蔵合金, 水素吸蔵回数・放出回数

\section{1.はじめに}

地球環境に負荷を与えないエネルギーシステムとして， 水素エネルギー・システムを地球規模で構築することが提 唱されている(1) 。水素エネルギー・システムの1つに， 太陽電池と燃料電池を組み合わせた太陽光発電・燃料電池 ハイブリッドシステムがある(3)(4) (5)。このシステムは宣間 に太陽光発電システムで発生した電力を直接負荷に供給 し，余剩電力を利用して水素を製造，眝蔵する。夜間等は 太陽光発電システムで負荷への十分な電力供給が困難であ るので,この貯蔵した水素を燃料として, 燃料電池で電力 変換し負荷に電力を供給するシステムである。また，この システムは独立型電源システムであり，負荷に電力を安定 供給するためには電力貯蔵装置が必要となる。そこで，電 力眝蔵装置として水素を媒体とする水素吸蔵合金を用いた 水素貯蔵装置を導入した。水素貯蔵装置は, 複数台の水素
貯蔵容器で構成されている。ここで水素貯蔵容器とは合金 形成体と熱交換器とを具備したものである。水素吸蔵合金 の種類は LaNi5 とした。LaNi5 は $6.2 \mathrm{~g}$ で標準状態の水素 $1 l$ 眝蔵可能である(6)。

本論文では，太陽光発電・燃料電池ハイブリッドシステ ムに水素貯蔵装置を用いたシステム特性について論述した ものである。負荷は住宅用負荷を想定し，年間負荷電力量 $400 \mathrm{MWh}$, 平均負荷電力 $45.7 \mathrm{~kW}$ である。負荷に電力を 安定的に供給するために水素貯蔵装置として複数台の水素 眝蔵容器を導入し，その際の各水素吸蔵合金の容量, 水素 の吸蔵回数・放出回数特性をシミュレーションにより比較 検討した。ここで，吸蔵回数とは水素を吸蔵する月毎ある いは年間の積算回数のことであり，放出回数とは水素を放 出する月毎あるいは年間の積算回数のことである。

比較検討した結果，年間を通して負荷に電力を安定的に 供給するためには，太陽電池アレイの容量が $745 \mathrm{~kW}$ ，水 
素吸蔵合金の総容量が 259.2 ton 必要となることが分かっ た。また，水素吸蔵回数と放出回数はそれそれ 1039 回/年, 1739 回/年となることが分かった。

\section{2. システム構成}

図 1 にシステム構成図（3台の水素貯蔵容器）を示方。 太陽電池アレイ, DC-DCコンバータ, 水素発生機, 水素 眝蔵装置, 然料電池, インバータで構成されている。水素 貯蔵装置とは複数台の水素貯蔵容器で構成されているもの とする。このシステムは, 昼間に太陽電池アレイで発生し た電力をインバータを介して負荷に供給しつつ, 余剩電力 を利用して水素発生機で水の電気分解を行い水素を製造 し，水素吸蔵合金に貯蔵する。また，太陽電池アレイのみ で負荷への十分な電力供給が困難なときに, 貯蔵した水素 を燃料電池を介して負荷に電力を供給する。

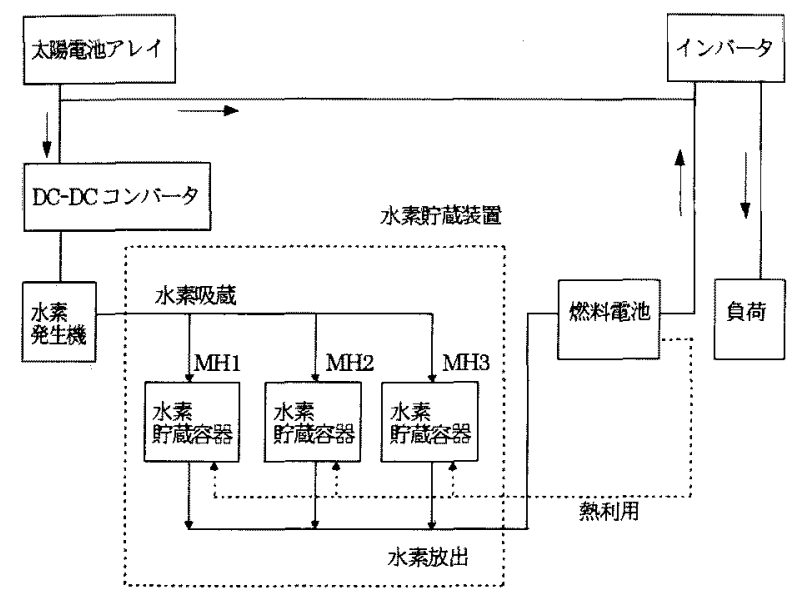

図1システム構成図

Fig.1. System configuration.

〈2・1〉太陽電池アレイ 太陽電池の基本構造は PN 接合であり, 一般に太陽電池の光照射状態でのI-V 特性式 は並列抵抗が無限大と仮定すると，(1)式で表される(7)。

$$
I=I_{L}-I_{o}\left\{\exp \left[\left(V+I R_{S}\right) / a\right]-1\right\}
$$

ここで, $I$ : 出力電流 $[\mathrm{A}], V:$ 出力電圧 $[\mathrm{V}], I_{L}$ : 光起電流 $[\mathrm{A}], I_{o}$ : 飽和電流 $[\mathrm{A}], R_{S}$ : 直列抵抗 $[\Omega]$, $a: I$ V 特性力ーブに合わせるためのパラメータ

直列抵抗 $R_{S}$ は各太陽電池モジュールによって值が異な るので次式から求めた ${ }^{11}$ 。

$$
R_{S}=\frac{a \ln \left(1-\frac{I_{m p}}{I_{L}}\right)-V_{m p}+V_{o c}}{I_{m p}}
$$

ここで, $V_{o c}$ : 開放電圧 $[\mathrm{V}], V_{m p}$ : 最大出力動作 電圧 $[\mathrm{V}], \quad I_{m p}:$ 最大出力動作電流 $[\mathrm{A}]$

光起電流 $I_{L}$ と飽和電流 $I_{o}$ はセル温度 $T_{c}$ の関数として表
すことができ，セル温度は本学屋上にて測定中の多結晶シ リコン太陽電池モジュール（地上 $40 \mathrm{~m}$, 傾斜角 $35.5^{\circ}$, 南 向きに設置）のデータ（測定期間 1994 年 3 月〜 1995 年 2 月）を基に以下のように想定した。

$$
\begin{aligned}
& T_{c}=T_{a}+\Delta T+273.15 \\
& \Delta T=b I_{r r}+c
\end{aligned}
$$

ここで, $T_{c}$ : セル温度 $[\mathrm{K}], T_{a}:$ 外気温度 $\left[{ }^{\circ} \mathrm{C}\right]$, $\Delta T$ : セル温度と外気温度との差 $\left[{ }^{\circ} \mathrm{C}\right], b, c$ : 定数, $I_{r r}$ : 太陽電池面入射日射強度 $\left[\mathrm{W} / \mathrm{m}^{2}\right]$

上記に示した(1)〜(4)式により，ある太陽電池面入射日 射強度とセル温度の際の最大出力電流 $I_{\max }$ と最大出力電圧 $V_{\text {max }}$ を計算した。

太陽電池アレイの発生電力は(5)式のように求めた。

$$
P_{\text {array }}=I_{\max } V_{\max } N_{m}
$$

ここで, $P_{\text {array }}$ : 太陽電池アレイ発生電力 $[\mathrm{W}]$, $N_{m}:$ 太陽電池モジュール枚数

表 1 に太陽電池モジュールの仕様を示す

表1 太陽電池モジュール仕様

Table 1. Specifications of PV module.

\begin{tabular}{c|c}
\hline 太陽電池モシュール種類 & 単結晶シリコン \\
\hline 最大出力 $P_{\max }$ & $109.2 \mathrm{~W}$ \\
\hline 開放電圧 $V_{o c}$ & $44.0 \mathrm{~V}$ \\
\hline 短絡電圧 $I_{s c}$ & $3.46 \mathrm{~A}$ \\
\hline 最大出力動作電圧 $V_{m p}$ & $35.0 \mathrm{~V}$ \\
\hline 最大出力動作電流 $I_{m p}$ & $3.12 \mathrm{~A}$ \\
\hline
\end{tabular}

〈2・2〉 DC-DCコンパータＤC-DCコンバータは 太陽電池アレイの発生電力を制御する機能を有し，特に太 陽電池アレイの出力電圧を水素発生機の所定の入力電压に 調整する働きがある。ここでは，DC-DCコンバータの変 换効率を定格容量に対する負荷率に関係なく96.0\%一定と した ${ }^{(8)}$ 。

$\langle 2 \cdot 3\rangle$ 水素発生機水素発生機は, 固体高分子電解 質水電解方式で水の電気分解を行い水素を得ると想定した。 この方式は電極触体とイオン交換膜とを一体化した膜一電 極接合体を用い，イオン交換膜は電解質と隔膜の両役割を はたしている。その特改は, 電解液が不要, 高い電流密度, 純度の高い水素を得ることができるなどがある。水素発生 機の変換効率を $90.0 \%$ とした ${ }^{(10)} 。$

〈2.4〉 水素貯蔵容器水素貯蔵容器は合金形成体と 熱交換器とを具備したもので，次の条件で構成されている。 (1) 水素吸蔵合金の種類は LaNi5 とする。 LaNi5 は, $6.2 \mathrm{~g}\left(0.9 \mathrm{~cm}^{3}\right)$ で標準状態の水素を $1 l$ 貯蔵することが できる(6)。

（2）10 気圧の水素を水素吸蔵合金に圧入させ，常温で 2 気 压の水素を水素吸蔵合金より噴出させるものとする。

(3) 水素吸蔵合金に水素を吸蔵させる際, 発熱を伴うが冷 
却水 $20.0^{\circ} \mathrm{C}$ を循環させ水素吸蔵合金を泠却するものと する。また，水素を放出させる際，吸熱を伴うが燃料 電池からの排熱を利用して温水 $70.0^{\circ} \mathrm{C}$ 循環させ水素 吸蔵合金に熱量を与えるものとする。

(4) 水素の吸蔵放出速度は常蕰で十分に速いとする。

(5) 水素の吸蔵放出は合金のプラト一領域で行われるもの とする。合金に貯蔵可能な水素量を 1.0 とすると，プ ラト一領域での有效な水素量は 0.8 とする゙1!。すなわ ち，6.2 g の LaNi5 では，有効な水素量は $0.8 l$ となる。 一般的に，水素吸藏合金 $M$ と水素 $H_{2}$ との反応は次式で 表される。

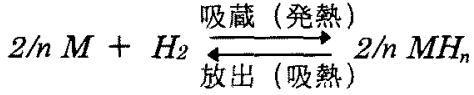

また, 水素圧力 $P_{H 2}$ と温度 $T$ のファント・ホッフの関係 式より,

$$
\begin{aligned}
& \ln P_{H 2}=\frac{\Delta H^{0}}{R T}-\frac{\Lambda S^{0}}{R} \quad \cdots \cdots(7) \\
& \text { ここで, } \triangle H^{0}: \text { エンタルビ一変化量 }\left[\mathrm{J} / \mathrm{molH}_{2}\right], \\
& \triangle S^{0}: \text { エントロビー変化量 }\left[\mathrm{J} / \mathrm{K} \cdot \mathrm{molH}_{2}\right], T: \text { 絶 } \\
& \text { 対温度 }[\mathrm{K}], R: \text { 気体定数 }\left[\mathrm{J} / \mathrm{K} \cdot \mathrm{molH}_{2}\right]
\end{aligned}
$$

となる。

(7)式にLaNi5のエンタルピー変化量（ $\mathrm{LH}^{0}=$ $\left.-30.1 \mathrm{k} \mathrm{J} / \mathrm{mol} \mathrm{H}_{2}\right)$ とエントロビー変化量（ $\triangle S^{0}=$ $-108.8 \mathrm{~J} / \mathrm{K} \cdot \mathrm{molH} 2)$ を代入し，その際の温度の逆数に刘 する解離圧の対数の関係をプロットすると図 2 のようにな る(1!)。図より，直線の勾配が大きいものほどエンタルピ一 変化量の絶対值が大きく，より安定な水素化物を作りやす い，また水素化物が合金と水素に解離するのにより高温を 必要とするということが分かる。解離圧 2 気圧の時，温度 $20.0^{\circ} \mathrm{C}$ となことも分かる。

この反応は単純な吸着現象などではなく金属原子のつく る格子間隔に水素原子が入り込む化学反応である。反応の 特徴として，可逆性に優れている，反応速度が速い，反応

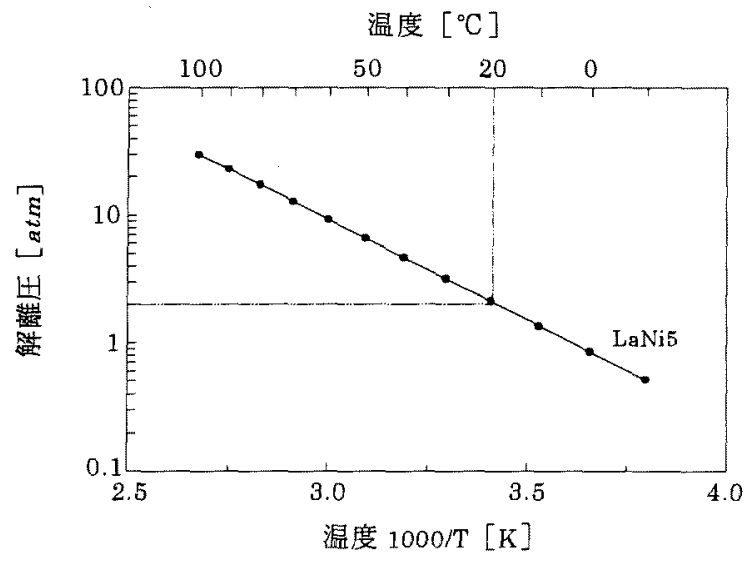

図 2 温度に対する解離圧の関係

Fig.2. Relationship between $\mathrm{MH}$ temperature and hydrogen pressure
熱が大きいなどがあげられる。この水素貯蔵容器内の水素 吸蔵合金の吸蔵效率・放出効率は，水素の吸蔵・放出の際 の膨張・収縮により微粉化される影響を考虑してそれそれれ $96.0 \%$ あるとした ${ }^{(13)}$ 。

〈2.5〉 燃料電池燃料電池としては，作動温度 $190 \sim 210^{\circ} \mathrm{C}$ 程度のリン酸塩型燃料電池を想定した。単電池 はリン酸を含浸，保持した電解質マトリックスとそれを挟 んで対向する一対の多孔性ガス拡散電極から構成される。 この単電池の出力電圧は $0.7 \mathrm{~V}$ と低いので, 単電池をセパ レータを介して積㬝し直列に接続して燃料電池（本体）を 構成するものとする。

図 3 に燃料電池と水素貯蔵容器との熱収支の一例を示す。 昼間は水素貯蔵容器の媒体入口温度 $20^{\circ} \mathrm{C}$, 燃料電池温度 $50{ }^{\circ} \mathrm{C}$ となるうに制御する。また，夜間は水素貯蔵容器 の媒体入口温度 $70^{\circ} \mathrm{C}$, 燃料電池温度 $190{ }^{\circ} \mathrm{C}$ となるように 制御する(14)。

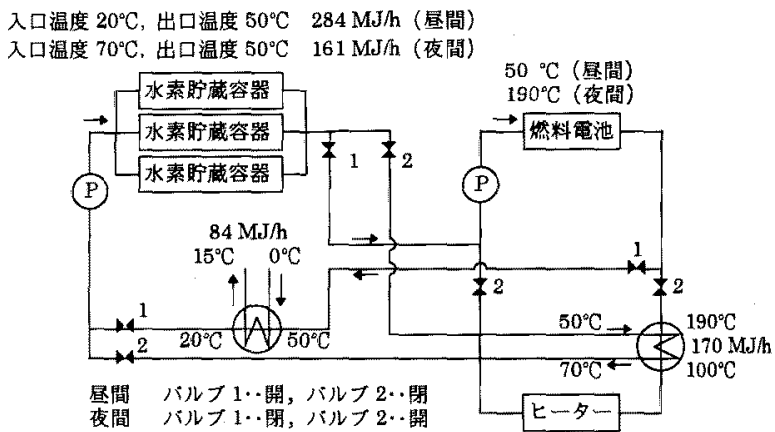

図 3 燃料電池と水素貯藏容器との熱収支

Fig.3. Heat balance between fuel cell and hydrogen storage tank.

したがって，本論文のシミュレーションでは以下の条件 で稼働するものとする。

（1）燃料電池の起動・停止は瞬時に行われるものとする。

（2）燃料電池の発電効率を定格容量に対する負荷率に関 係なく $40.0 \%$ 一定であるものとする。

（3）然料電池の排熱を水素貯蔵容器で使用する。

〈2・6〉インバータ インバータは，太陽電池アレイ や然料電池からの直流電力を交流電力に変換するもので, 発生電力を制御する機能も有するものである。また，イン バータの変換効率を負荷率に関係なく $96.0 \%$ 一定としだ。

\section{3. シミュレーション条件と方法}

シミュレーションの流れ図を図 4 に示す。シミュレーシ ヨンするにあたって，システムの入カデータは環境データ， 負荷データ，それぞれの構成要素の変換効率などであり， 1 年間のデータについて 1 時間毎に繰り返し計算して，水 素貯蔵容器内の水素吸蔵合金容量, 水素の吸蔵回数・放出 回数などを求めた。吸蔵回数とは水素を吸藏する月毎ある いは年間の積算回数のことであり，放出回数とは水素を放 出する月毎あるいは年間の積算回数のことである。シミュ 


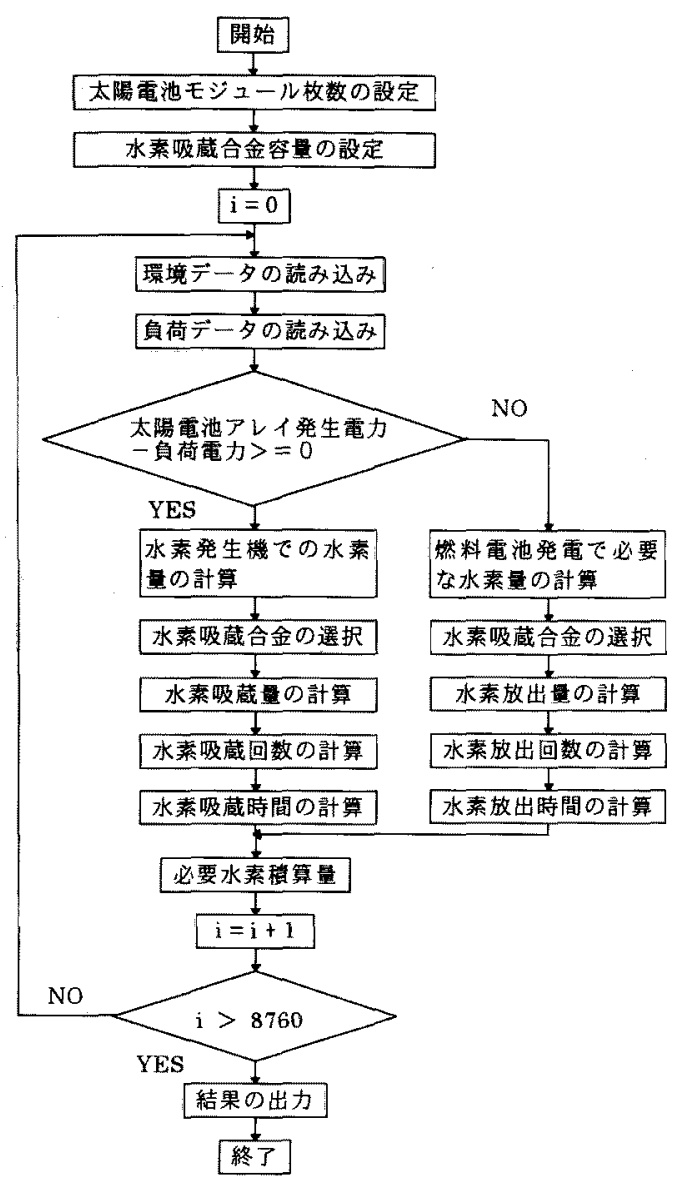

図 4 流れ図

Fig.4. Flow chart.

レーションでは 3 台 $(\mathrm{MH} 1, \mathrm{MH} 2, \mathrm{MH} 3)$ に分割した際に， 年間を通して負荷に電力を安定的に供給するための水素貯 蔵装置の吸蔵・放出特性について詳細に行った。1 時間毎 に各水素貯蔵容器内の貯蔵量を比較し, 水素の吸蔵は最小 眝蔵量の水素貯蔵容器で行われる。逆に, 水素の放出は最 大眝蔵量の水素貯蔵容器で行われる。なお, 燃料電池発電 で必要な水素量は, 理論上 $1 \mathrm{~mol}$ の水素から $65.9 \mathrm{Wh}$ の電 気エネルギーが得られるが，この值の $40.0 \%, 26.4 \mathrm{Wh}$ で $1 \mathrm{~mol}$ とした。以下に, 環境データ, 負荷データと負荷形 状率, 構成要素の変換効率を示す。

〈3.1〉環境データ太陽電池アレイの入力環境デー 夕には HASP データ(東京) の連続する 1 時間毎 (8760 時 間)の日射データと外気温度データを使用した。HASP デ ータとは，標準気象データのことで，気温，湿度，直達日 射, 散乱日射, 雲量, 風速などの毎時のデー夕を整備した ものである。なお, 傾斜面全天日射強度 $\Phi\left[\mathrm{W} / \mathrm{m}^{2}\right]$ への変 換は日射データの直達日射強度 $\Phi_{d}\left[\mathrm{~W} / \mathrm{m}^{2}\right]$ と散乱日射強度

$\Phi_{g}\left[W / \mathrm{m}^{2}\right]$ とを用いて，以下のように計算した。

$$
\begin{aligned}
& \Phi=\Phi_{d} \cos \delta \cos t+\Phi_{g}(1+\cos L) / 2 \cdots \cdots(8) \\
& \text { ここで, } \delta: \text { 太陽赤緯 }\left[{ }^{\circ}\right], t: \text { 時角 }\left[{ }^{\circ}\right], L: \text { 太陽電 }
\end{aligned}
$$

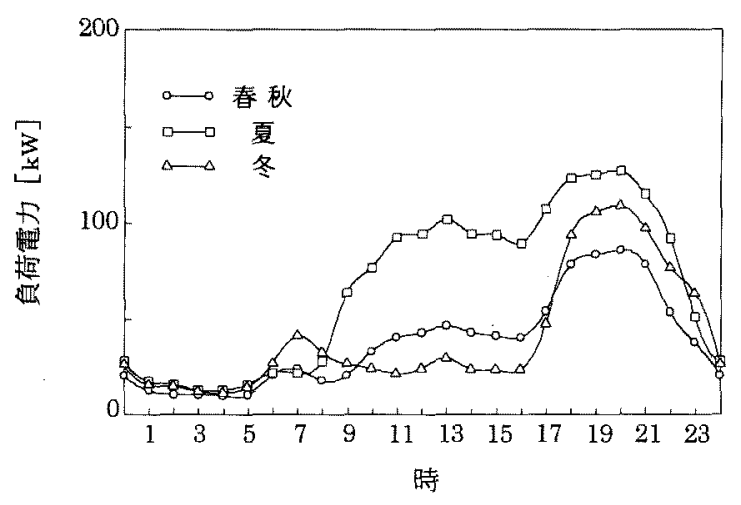

図 5 負荷パターン

Fig.5. Electric load pattern .

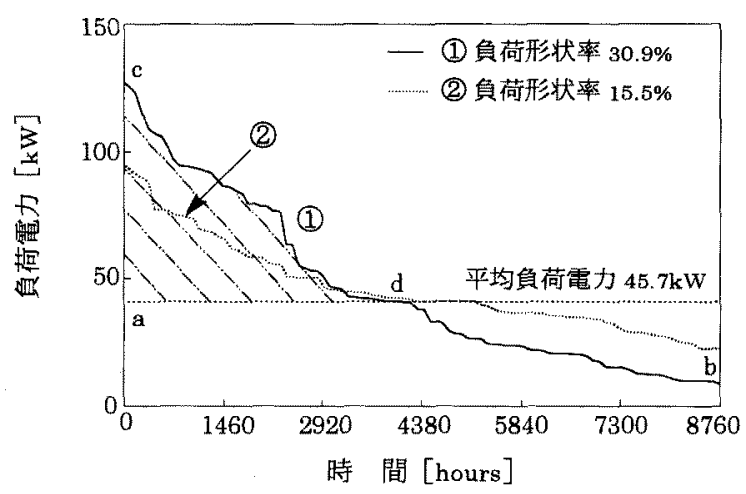

図 6 負荷形状率

Fig.6. Electrical load-form factor

表 2 構成要素の変換効率

Table 2. Conversion efficiency of subsystem.

\begin{tabular}{c|l}
\hline 構成要素 & 変換効率 $[\%]$ \\
\hline DC-DC コンバータ & 96.0 \\
\hline 水素発生機 & 90.0 \\
\hline 水素貯蔵容器 & 96.0 (吸蔵時) \\
(LaNi5) & 96.0 (放出時) \\
\hline リン酸塩型燃料電池 & 40.0 (電力) \\
\hline インバータ & 96.0 \\
\hline
\end{tabular}

池アレイの設置傾斜角度 $\left.{ }^{\circ}\right]$

〈3·2〉負荷データと負荷形状率負荷データは，モ

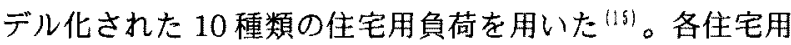
負荷の年間負荷電力量をそれそれ 4000kWh（一軒に相 当）に規格化して，この值の 100 倍分（年間負荷電力量 $400 \mathrm{MWh}$, 平均負荷電力 $45.7 \mathrm{~kW}$ ) を想定した。また, 負 荷デー夕は春期（ 3 月〜 5 月），夏期 ( 6 月〜8月）, 秋 期 (9月〜11月), 冬期 (12月〜2月) の4種類とし, 各 期間ではいずれも同一とした。図 5 に負荷バターンを示す。 ここで住宅用負荷を分類する一つの指標として，負荷形状 率を定義する ${ }^{[16)}$ 。図 6 に負荷形状率の一例を示す。負荷形 状率とは，年間の負荷電力量に対する平均負荷レベル以上 
の負荷電力量の割合である。図より, 負荷形状率は (0acdb8760に囲まれた面積) と（acd に囲まれた面積） との割合である。ここで用いた 10 種類の負荷形状率の内 訳は, $10.1 \% \sim 15.5 \%$ が 7 種類で $25.1 \% \sim 30.9 \%$ が 3 種類 である。

〈3.3〉構成要素の変換効率 表 2 にシステムを構成 する各要素の変換効率を示す(1) (10) (11) (12) (13)。

\section{4. 結果}

本システムは年間を通して負荷に電力を供給する独立型 エネルギー供給システムである。本論文では年間水素吸蔵 量の樌算値を $H_{c}$, 年間水素放出量の積算値を $H_{d}$ とすると, $H_{c}-H_{d}=0$ となるシステムについて考察した。

表 3 システムの概要（負荷形状率 $30.9 \%$ )

Table 3. Summary of system (electrical load form factor $30.9 \%$ ).

\begin{tabular}{c|c}
\hline 構 成 要 素 & 容 量 \\
\hline $\begin{array}{c}\text { 太陽電池アレイ } \\
\text { (単結晶シリコン) }\end{array}$ & $\begin{array}{c}745 \mathrm{~kW} \\
(984 \mathrm{MWh} / \mathrm{y})\end{array}$ \\
\hline $\mathrm{DC}-\mathrm{DC}$ コンバータ & $100 \mathrm{~kW} \times 7$ 台 \\
\hline 水素発生機 & $100 \mathrm{~kW} \times 7$ 台 \\
(固体高分子電解質水電解) & $\left(34,800 \mathrm{Nm}^{3} / \mathrm{y} \times 7\right)$ \\
\hline 水素吸蔵合金 $(\mathrm{LaNi5})$ & $86.4 \mathrm{ton} \times 3$ 台 \\
\hline リン酸塩型燃料電池 & $150 \mathrm{~kW}$ \\
\hline インバータ & $150 \mathrm{~kW}$ \\
\hline
\end{tabular}

表 3 に負荷形状率 $30.9 \%$ のさのシステムの概要を示す。 太陽電池アレイは 6822 枚のモジュールで構成されている ことが分かった。また, 3 台の水素貯蔵容器のうち 1 台の 水素吸蔵合金の容量は 86.4 ton となることも分かった。太 晹電池アレイ容量が, リン酸塩型燃料電池やインバー夕容 量と比較して 5 倍と大容量となる理由は，すでに報告した ようにこれに類する太陽光発電・燃料電池ハイブリッドシ ステムの年間システム効率が $7.5 \%$ と低いことよる(3)。

図 7 に負荷形状率に対する水素眝蔵容器内の水素吸蔵合

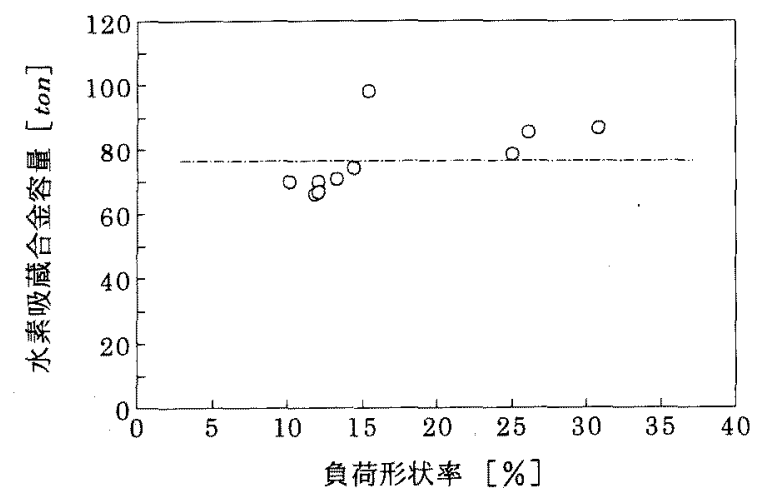

図 7 負荷形状率に対する水素吸蔵合金容量の関係

Fig.7. Relationship between electrical load-form factor and capacity of hydrogen absorbing alloys.

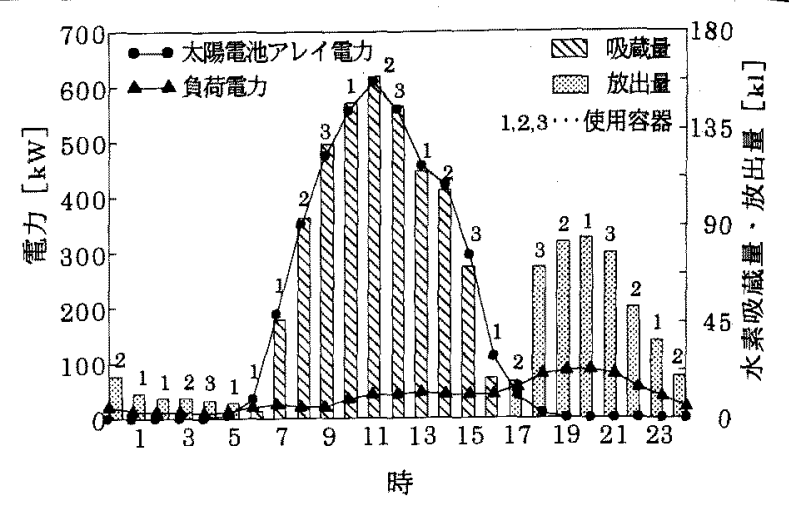

図 81 日の稼働状況

Fig.8. Characteristics of operation in a day.

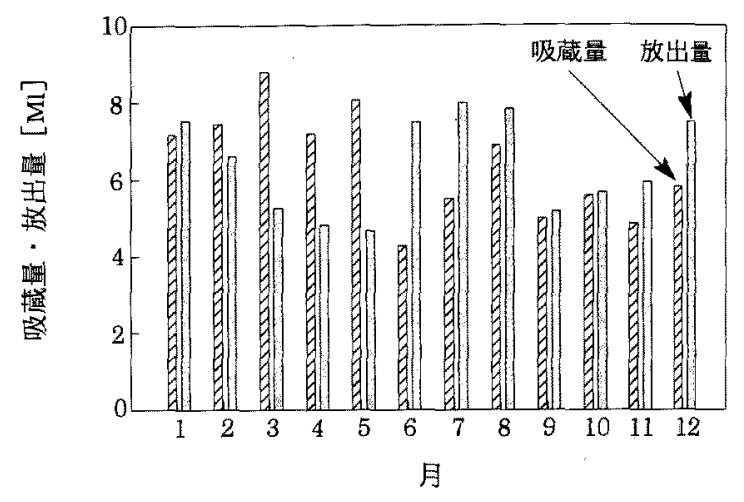

図9月別水素の吸藏量・放出量の関係（容器 1 台）

Fig.9. Monthly volume of hydrogen absorption / desorption (hydrogen absorbing tank per one).

金容量の関係を示す。負荷形状率の変化に対する水素吸蔵 合金容量は, $65.7 \sim 97.8$ ton で, その平均値は 76.1 ton と なった。平均値に対する最大値, 最小値の偏りは, それぞ れ，28.5\%，-13.7\%となり，負荷形状率の違いにより， 水素吸蔵合金容量は大きく変化することが分かった。

図 8 に本システムの1日の稼働状況の一例を示す。図は 快晴日(9月 13 日)の稼働状況で，6時から 16 時にかけて 水素を吸蔵し，0時から 5 時，17時から 24 時にかけて水 素を放出していることが分かった。なお，図中の $1 ， 2 ３$ は使用容器の番号で, 水素貯蔵容器 3 台としたときのもの である。その内の 1 台について月毎に吸蔵量・放出量を積 算したものを図 9 に示す。また，月毎に吸蔵回数・放出回 数を積算したものを図 10 に示す。年間を通して，3台の 水素貯蔵容器毎に吸蔵回数・放出回数を積算したものを 図 11 に示す。ここで, 吸蔵回数・放出回数とは吸蔵量· 放出量に関係なく使用容器の切り替え時を 1 回とした。

図 9 に月別水素の吸蔵量・放出量の関係（3台の容器の うち 1 台)を示す。負荷形状率 $30.9 \%$ の时である。図より， 1月〜 5 月の期間に水素を吸蔵し 6 月〜 12月の期間に水素 を放出していることが分かる。吸蔵量は 3 月に最大值 $8.8 \mathrm{Ml}, 6$ 月に最小值 $4.2 \mathrm{Ml}$ となる。放出量は 7 月に最大 值 $8.0 \mathrm{Ml}, 5$ 月に最小值 $4.7 \mathrm{Ml}$ となる。また, 年間を通し 


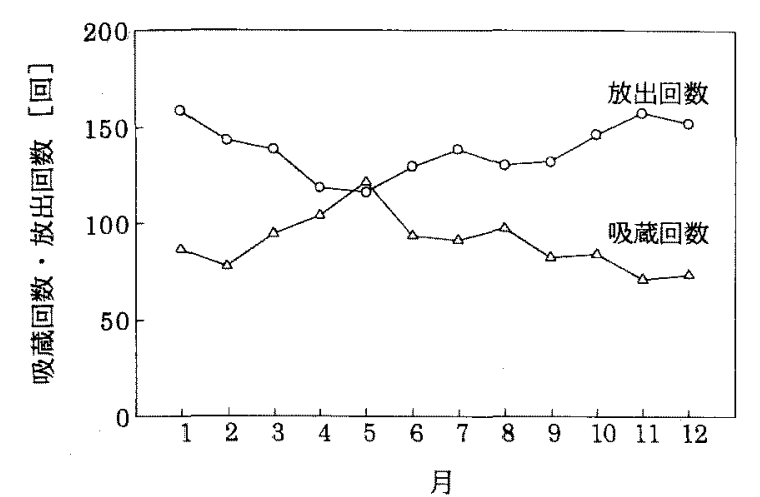

図 10 月別水素の吸蔵回数 - 放出回数の関係 (容器 1 台) Fig.10. Monthly number of hydrogen absorption / desorption (hydrogen absorbing tank per one).

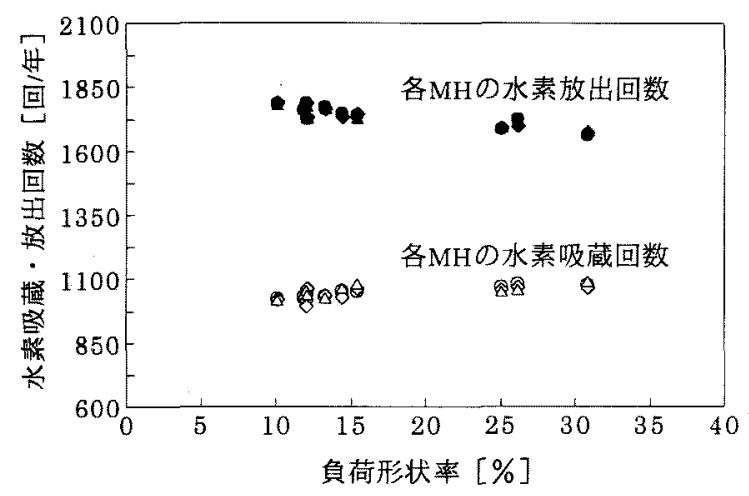

図 11 負荷形状率に対する水素吸藏・放出回数の関係

Fig.11. Relationship between electrical load-form factor and number of hydrogen absorption / desorption.

て水素吸蔵量の積算値と水素放出量の積算値とは等しい。 図 10 に月別水素の吸蔵回数・放出回数の関係（3台の 容器のうち 1 台)を示す。負荷形状率 $30.9 \%$ の時である。 ここで吸蔵回数とは水素を吸蔵する月每の積算回数のこと である。また，放出回数とは水素を放出する月毎の積算回 数のことである。図より，吸蔵回数は 5 月に最大值 121 回/月となり，逆に放出回数は 5 月に最小値 116 回/月 となる。また, 吸蔵回数 1 回当たりの平均水素吸蔵量は, 2 月に最大値 $96.4 \mathrm{kl}$ 回, 6 月に最小值 $45.6 \mathrm{kl}$ 回となる。こ れらの值は合金に眝蔵可能な水素量を $100 \%$ とした時にそ れそれ $0.69 \%, 0.33 \%$ に相当する。同様に放出回数 1 回 当たりの平均水素放出量は, 8 月に最大值 $60.1 \mathrm{kl}$ 回， 11 月に最小値 $37.7 \mathrm{kl} /$ 回となる。これらの值は合金に貯蔵 可能な水素量を $100 \%$ とした時にそれそれ $0.43 \%, 0.27 \%$ に相当することが分かった。

図 11 に負荷形状率に対する水素吸蔵・放出回数の関係 (3 台の容器)を示す。吸蔵回数とは水素を吸蔵する年間積 算回数のことであり，放出回数とは水素を放出する年間積 算回数のことである。図より，負荷形状率の変化に対する 水素吸蔵回数は 1039 回/年となり，また，水素放出回数は 1739 回/年となった。吸蔵回数と放出回数との差が大きい

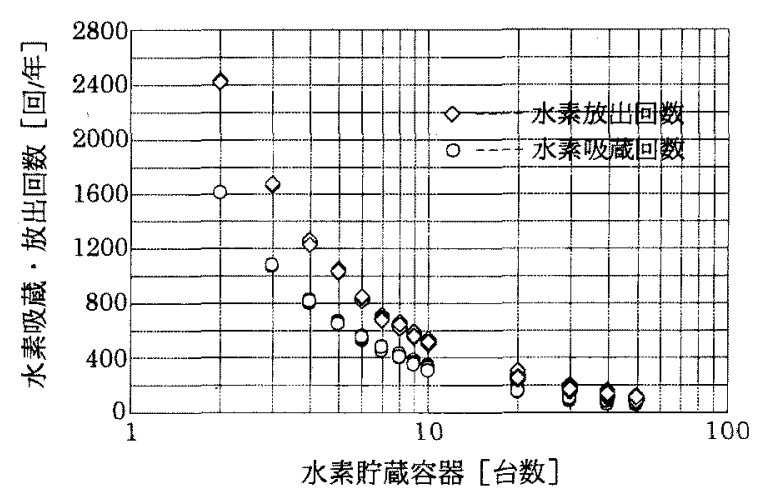

図 12 水素貯蔵容器台数に対する水素吸蔵・放出回数の関係 Fig.12. Relationship between number of hydrogen storage tank and hydrogen absorption / desorption.

が,このことはシステムの夜の稼働時間が昼の稼働時間よ り 1.5 倍大きいことによる。すなわち, 太陽電池アレイの 稼働時間が 3377 時間で, 燃料電池の稼働時間が 5383 時 間となることによる。

図 12 に水素貯蔵容器台数に対する水素吸蔵・放出回数 の関係を示す。例として負荷形状率 $30.9 \%$ のときである。 ここで水素貯蔵容器とは合金成形体と熱交換器とを具備し たものである。図より, 容器台数の増加に対し水素吸蔵・ 放出回数は，反比例的に減少することが分かった。容器の 台数を 50 台とすると，吸蔵回数は 67 回/年，放出回数は 104 回/年となった。その際の 1 台当たりの水素吸蔵合金容 量は 5.0 ton となった。水素貯蔵容器の容量は, 材料の種 類，熱交換器の特性などによって決定される。例えば，水 素貯蔵容器の放出回数が 10,000 回まで正常に動作したと 仮定し耐用年数が 10 年とすると， 1 台当たり 51.9 ton の 合金が 5 台必要となることも分かった。

吸蔵・放出サイクルは， 3 千から 1 万サイクル程度とさ れている(13)。また，LaNisにおいては，3千サイクル後の 水素吸蔵量は 1 回目とほとんど変わらないとされている。 ここでの吸蔵・放出サイクルとは貯蔵可能量まで吸蔵し, 次いで放出することを 1 サイクルとしている。筆者らが提 案している水素眝蔵容器の使用方法は部分吸蔵・部分放出 であり，今後実状にあった検討が必要であるが，本論文で は繰り返しによる吸蔵量・放出量への影響はないとした。

\section{5. おわりに}

筆者らは太陽光発電 ·燃料電池ハイブリッドシステムに 水素貯蔵装置として複数台に分割した水素貯蔵容器を導入 し, その際の各水素吸蔵合金 $\left(\mathrm{LaNi}_{5}\right)$ の吸蔵回数・放出回 数の均質性について，シミュレーションにより比較検討し た。なお，検討したシステムの住宅用負荷は年間負荷電力 量 400MWh であり, 負荷形状率は 10.1〜 30.9\%の 10 種類 である。

その結果以下のことが明らかになった。なお, 結果 (1) 〜 (3)は 3 台に分割した水素貯蔵容器の 1 台当たりの水素 
の吸蔵・放出特性について示した。

（1）負荷形状率の変化に対して水素貯蔵容器内の水素吸蔵 合金容量は，65.7 97.8 ton でその平均値は 76.1 ton となることが分かった。このことは, 負荷形状率の違 いにより, 水素吸蔵合金容量は大きく変化することが 分かった。

（2）月別水素の吸蔵量 - 放出量の推移は， 1 月〜 5 月の期 間に水素を吸蔵し 6 月〜 12 月の期間に水素を放出して いることが分かった。

（3）年間の水素吸蔵回数 - 放出回数は, 負荷形状率の変化 に対して, 水素吸蔵回数 1039 回/年, 水素放出回数 1739 回/年となり,ともにほほ一定となることが分か った。

(4) 水素貯蔵容器台数の増加に対する水素吸蔵 - 放出回数 は, 反比例的に減少することが分かった。容器の台数 を 50 台とすると, 吸蔵回数は 67 回/年, 放出回数は 104 回/年となった。その際の 1 台当たりの水素吸蔵合 金容量は 5.0 ton となった。また, 例えば, 水素貯蔵 容器の放出回数が 10,000 回まで正常に動作したと仮 定し耐用年数が 10 年とすると, 1 台当たり 51.9 ton の合金が 5 台必要となることも分かった。

(平成 8 年 5 月 27 日受付, 同年 10 月 22 日再受付)

\section{文献}

（1）本間玩也:「WE-NET 構想(総合プロジェクトの国際展開 ーエネルギー・環境問題の同時解決-)」, 第 12 回工業技術 院筑波総合シンボジウム, p.75 (1993-3)

( 2 ) Yoichi Kaya ;"FUTURE ENERGY SYSTEMS AND THE ROLE OF HYDROGEN ", International Hydrogen and Clean Energy Symposium '95, p.3 (1995-2)

（３）関ロ・藤木·谷:「太陽光発電·燃料電池ハイブリッドシス テムの特性(負荷形状率による影響)」, 電学論 $\mathrm{B}, 114$, 403 (1994-4)

（4）関口・石井·谷:「太陽光発電·燃料電池ハイブリッドシス テムの年間特性(システムバラメータによる影響)」, 太 陽エネルギー, 21，3(1995-5)

( 5 ）関口·谷:「太陽光発電・燃料電池ハイブリッドシステム のシミュレーション（水素吸蔵合金を用いたシステムの 特性)」, 1751 , 平成 8 年電気学会全国大会 (1996-3)

（6）秋葉悦男: セラミックス, 25 巻, 5 号, p.441 446, (1990)

( 7 ) John A. Duffie, William A. Beckman ; "SOLAR
ENGINEERING of THERMAL PROCESSES", A WileyInterscience Publication, John Wiley \& Sons, Inc. , p. $770 \sim$ p.781 (1991)

（８）黒川·若松:「太陽光発電システムの設計ガイドブック」, オーム社, p.197 (1994)

（９）星野·工藤・木村·塩谷:「太陽光発電システムにおける DC-DC コンバータおよびインバー夕に関する研究」, 電 気学会半導体電力変換研資, SPC-88-36 (1988)

(10) Hiroyasu Takenaka; "R\&D ON SOLID POLYMER ELECTROLYTE WATER ELECTROLYSIS IN JAPAN", International Hydrogen and Clean Energy Symposium '95, p.165 (1995-2)

（11）太田時男:「水素エネルギー最先端技術」，（株） NTR， p.209, p.218, p.224 (1995)

(12) 若尾慎二郎ら $:\left\ulcorner\mathrm{MmNi}_{5}\right.$ 及び $\mathrm{Mg}_{1.85} \mathrm{Ni}$ 合金の水素吸蔵速 度」，東海大産研報， 11, p. $75 \sim 82$ (1980)

（13）大角泰章: ‘水素吸蔵合金一その物性と応用一」, (株) ア グネ技術センター, p.144, p.215 (1993)

（14）社団法人 日本機会学会:「伝熱ハンドブック」, 丸善(株), p.302 (1993)

（15）新エネルギー総合開発機構 (委託先 財団法人 電力中央 研究所): 昭和 60 年度調査報告書 23 「太陽光発電システ 厶の価值評価に関する調查研究( II )」, p.66 (1986-3)

(16) 田辺·安田・横山: $\left\ulcorner\mathrm{CO}_{2}\right.$ 排出抑制下における電源ベストミ ックスの分析」, 電気学会新省エネルギー研資, ESC92-43 (1992)

関口 直俊 (学生員) 1969 年 8 月 7 日生。 1995 年 3

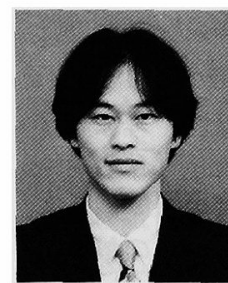
月東京理科大学大学院工学研究科電気工 学専攻修士課程修了。同年 4 月同大学院 工学研究科電気工学専攻博士課程入学。 現在，同課程において太陽エネルギー利 用技術に関する研究に従事。日本太陽工 ネルギー学会学生員。

谷辰夫（正 員）1940年 1 月 12 日生。1966 年 3

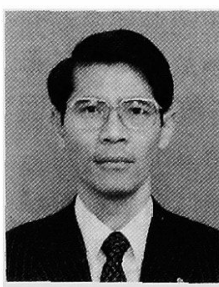
月名古屋工業大学大学院工学研究科修士 課程修了。同年 4 月通産省電気試験所 (現, 電子技術総合研究所) 入所。同工 ネルギー部太陽エネルギー研究室長を経 て, 1988 年 4 月東京理科大学工学部教 授，現在に至る。工学博士。エネルギー 変換工学担当。 